\title{
Association between Psychosocial Risk Factors and Quality of Work Life in Air Traffic Controllers at an Ecuador Airport
}

\author{
Luis Edmundo Sarabia-López ${ }^{1}$ Cecilia Colunga-Rodríguez ${ }^{2,3}$, Alfonso Mercado4, \\ Manuel Pando-Moreno ${ }^{3}$, María De Lourdes Preciado-Serrano ${ }^{3}$, José Luis Calderón-Mafud ${ }^{5}$, \\ Guido Germán Albán Pérez ${ }^{1}$, Marco Marcelo León-Navarrete ${ }^{1}$, Dorila Victoria Sarabia-Cruz ${ }^{6}$ \\ ${ }^{1}$ Facultad de Ciencias Psicológicas, Universidad Central del Ecuador, Quito, Ecuador \\ ${ }^{2}$ Centro Médico Nacional de Occidente, Instituto Mexicano del Seguro Social, Guadalajara, México \\ ${ }^{3}$ Centro Universitario de Ciencias de la Salud, Universidad de Guadalajara, Guadalajara, México \\ ${ }^{4}$ Department of Psychological Science, The University of Texas Rio Grande Valley, Edinburg, TX, USA \\ ${ }^{5}$ Facultad de Psicología, Universidad de Colima, Colima, México \\ ${ }^{6}$ Universidad Técnica Equinoccial, Quito, Ecuador \\ Email: cecilia.colunga@academicos.udg,mx
}

How to cite this paper: Sarabia-López, $\mathrm{L}$. E., Colunga-Rodríguez, C., Mercado, A., Pando-Moreno, M., Preciado-Serrano, M. L., Calderón-Mafud, J. L., Albán Pérez, G. G., León-Navarrete, M. M., \& SarabiaCruz, D. V. (2017). Association between Psychosocial Risk Factors and Quality of Work Life in Air Traffic Controllers at an Ecuador Airport. Psychology, 8, 1471-1481. https://doi.org/10.4236/psych.2017.810097

Received: July 1, 2017

Accepted: July 31, 2017

Published: August 3, 2017

Copyright $\odot 2017$ by authors and Scientific Research Publishing Inc. This work is licensed under the Creative Commons Attribution International License (CC BY 4.0).

http://creativecommons.org/licenses/by/4.0/ (c) (i) Open Access

\begin{abstract}
The aim of this research was to determine the association between psychosocial factors and Quality of Work Life (QWL) in air traffic controllers at an Ecuador airport. A transversal study was developed. The sample included 47 air traffic controllers of one airport in Quito, Ecuador. The participants answered an adapted version of the surveys "Factores Psicosociales en el Trabajo" (Psychosocial factors at work) and the "Calidad de vida en el trabajo" (Quality of work life) CVT-GOHISALO. The data analysis included descriptive statistics, $\mathrm{Z}$ scores and, association tests with chi-square and Spearman's rank correlation coefficient. The mean age was 40 years old, and most of the participants were males. For the psychosocial work factors, the higher mean score was for the dimension Work demands (22.94), followed by Workplace conditions (13.47). For the QWL the dimension Wellbeing accomplished through work (36.43) scored higher, followed by Institutional support for work (34.11). The findings indicated several positive associations between the study variables through the Spearman's Coefficient, observing that the psychosocial factor content and characteristic of the task presented the higher number of associations with QWL dimensions, such as Institutional support for work ( $p<$ $0.05)$, Work safety $(p<0.05)$, Integration to the work position $(p<0.05)$ and to Wellbeing accomplished through work $(p<0.05)$. The air traffic controllers develop a professional activity under work conditions that involve psychosocial factors that could represent an important risk for the health, satisfaction and QWL.
\end{abstract}




\section{Keywords}

Air Traffic Controllers, Spearman's Coefficient, Psychosocial Work Factors, Quality of Work Life

\section{Introduction}

The aeronautical industry has reach an important scientific and technological progress in the last century, being noticeable that in the last twenty years, the number of people traveling by this mean has doubled, promoting the development of more airports facilities (Sánchez \& Lina, 2008). The increase in the demand of this mean of transportation has made the security in the aircrafts a central topic. Nowadays, the aircraft security rests in two main actors, the aircraft crew and the air traffic controllers (ATCs).

The ATCs are in charge of the ground-based system that controls air traffic through the establishment of airways and separation standards between the plains. The activities developed by the ATCs during a common shift can be grouped into three categories: communication, which involves providing instructions to the pilots about the interactions with the airport and other aircrafts; flight process activities, involving the follow up of the aircrafts present in the flying zone; radar activities, such as adjustments (Vargas, Guimarães, \& Sant'Anna, 2012). One of the more stressful aspects of the ATCs job is the responsibility they have for human lives; according to Lopez (2012), and one air traffic controller has approximately 40 aircrafts under its responsibility in one hour, which implies that around 6000 human lives depend of its efficiency and psychophysics skills, only during that period.

The ATCs develop their work under conditions such as long shifts, night shifts, rotating shifts, mental demand, high level of pressure, among others, which represent factors that could involve a risk for their health. The air traffic controllers work conditions involve mostly, factors of a psychosocial nature. The psychosocial factors at work are described as work conditions derived from the interaction of the subject with the physical facilities, the organization, the procedures and methods, other workers, the work content and the task performance (Siegrist, 2007; Mansilla, 2012). When the psychosocial factors are present over time and with some level of intensity, they could originate a stress response, becoming a risk for the health at an emotional, cognitive, behavioral and physical level (Arenas \& Andrade, 2013). According to the control-demand model of Karasek, the work stress is regulated by the balance between the job psychological demands and the level of control perceived over those demands (Karasek \& Theorell, 1990).

Considering the ATCs work conditions, the air traffic control is defined as a high reliability profession, mainly because of the presence of psychosocial factors 
such as the requirement of high levels of mental alertness, the continuous self-monitoring and the high risk involve in the decision making (Sayeed \& Kumar, 2010; van de Merwe, Oprins, Eriksson, \& van der Plaat, 2012). These three factors represent a risk, because they can provoke mental exhaustion that can lead to the development of important physical and mental health problems, along with the impact they can have in the work experience, affecting areas such as performance, satisfaction, quality of work life, etc. (Crump, 1979).

The quality of work life (QWL) is an important construct influenced by the presences of psychosocial risk factors. QWL is defined as "a multidimensional concept that integrates when the worker, through the job and its own perception, perceives as covert all the personal necessities of: institutional support; security and integration to the job position; work satisfaction; identification of wellbeing accomplished through work; the personal development accomplished; as well as the free time administration" (González, Hidalgo, Salazar, \& Preciado, 2010). This evaluation of the work environment is based in objective conditions, such as work health, and, subjective conditions, such as the meaning provided to the work activity (Poza \& Prior, 1988). The QWL comes to summarize the balance between the personal and professional life, being a relevant aspect of the work life, because it has been associated with the job satisfaction and productivity (Kamali \& Chirayath, 2017).

The association between the psychosocial risk factors and the QWL is an important topic that has not been study in depth with this population. It is necessary to understand the influence that work conditions, that could represent a risk at a psychosocial level, have in the perception of the work experience. Considering this, the aim of this study was to determine the association between the psychosocial risk factors and work quality of life in air traffic controllers in an Ecuador airport.

\section{Research Settings}

Ecuadoris a Latin-American country with a population of $16,385,000$ people, the capital is Quito, with a population of 3 million people (Red de Seguridad y Defensa de América Latina, 2016). The country possesses 432 airports, being approximately 19 the commercial and operational (Central Intelligence Agency, 2013). There are 220 air traffic controllers currently working on these airports, having a mean age of 37 years (Maldonado, 2015).

This research was conducted in a commercial airport in Quito, Ecuador. The ATC's currently working in the facilities have work conditions such as night shifts, changing shifts, long shifts, constant supervision and high complexity tasks.

\section{Methodology}

\subsection{Participants}

The sample included 47 air traffic controllers of one commercial airport at Quito, Ecuador. The airport was selected through convenience sampling. We included 
all the air traffic controllers currently working in the airport for a period longer than six months.

\subsection{Instruments}

\subsubsection{Sociodemographic Data}

The sociodemographic data was collected through a one page form, in which the participants provided information about age, gender, school level and work seniority. The form was completed in a self-report system previously to the measurement instruments used for this research.

\subsubsection{Psychosocial Factors at Work}

The participants completed the adapted version of the survey "Factores Psicosociales en el Trabajo" (Psychosocial factors at work), administered in a self-report format (Silva, 2006). The instrument includes 46 items divided into 7 dimensions, which are, work place conditions (9 items), workload (5 items), content and characteristics of the task ( 7 items), work demands ( 7 items), professional role and career development (6 items), social interaction and organizational aspects ( 9 items) and performance remuneration ( 3 items). All the dimensions include items regarding the frequency in which the psychosocial factors are present at work, the answer options are in a five point Likert scale, going from never to always. The survey has a Cronbach's alpha of 0.9, being adapted to Peruvian population (Pando, Varillas, Aranda \& Elizalde, 2016).

\subsubsection{Quality of Work Life}

For the evaluation of the quality of work life, the participants answered an adapted version of the Spanish survey Calidad de vida en el trabajo (Quality of work life) CVT-GOHISALO, with a Cronbach's alpha of .961, for Mexican population. The instrument includes 74 questions about the degree of satisfaction with occupational aspects such as work safety, support, integration, etc. The items are divided into 7 dimensions: institutional support for work (14 items), work safety (16 items), integration to the job (10 items), work satisfaction (10 items), wellbeing accomplished through work (11 items), personal development ( 8 items) and free time administration (5 items). The answer options are in a five point Likert scale, going from not satisfy, to, very satisfy (González, Hidalgo, Salazar, \& Preciado, 2009).

\subsection{Data Collection}

We developed one initial session with the authorities at the airport, explaining the aims and methodology of the research. After, the participants assisted an informative debrief in which the aims, ethical considerations, measurement instruments and data collection procedure was explained. Subsequently, one-hour session was schedule with their direct bosses according to their work shifts. The main researcher conducted the surveys application, providing answering instructions and constant assistance. The participants answered the measurement 
instruments through a self-report system, in a writing format, at the workplace after work hours.

\subsection{Data Analysis}

Initially, we created a database in the SPSS, version 21.0 program. The information collected in the database was validated through a random check against the physical surveys.

At a first stage, the results from both surveys were submitted to descriptive statistics analysis, including frequencies, percentages, measurements of central tendency and dispersion, along with $\mathrm{Z}$ scores. During a second stage, we analyzed the association between the study variables with chi-square test, proceeding to apply the Spearman's rank correlation coefficient to determine the directionality of the association.

\subsection{Ethical Considerations}

The research was submitted for evaluation to the ethic committee of the Doctorado Interinstitucional en Psicología (Interinstitutional Doctorate in Psychology) from the University of Guadalajara.

The participants signed a inform consent form, in which it was explained that their participation would be voluntary and confidential, emphasizing that they would not receive any negative consequences from work in case they denied to participate in the research. No monetary or work remuneration was provided to the participants.

\section{Results}

The sample included 47 air traffic controllers, mostly man with a mean age of 40 years and a school level of bachelor's degrees. The work seniority was high, finding a mean of 17.62 years in the same work position (Table 1). Regarding the schedule, all the participants work in a 40 hours per week system, having mixed shifts in day and night.

Table 1. Sociodemographic data of the participants.

\begin{tabular}{|c|c|c|c|c|}
\hline \multicolumn{3}{|c|}{ Variable } & $\mathrm{n}$ & $\%$ \\
\hline \multirow{3}{*}{ Gender } & \multicolumn{2}{|c|}{ Female } & 5 & 10.6 \\
\hline & \multicolumn{2}{|c|}{ Male } & 42 & 89.4 \\
\hline & \multicolumn{2}{|c|}{ Middle school } & 11 & 23.4 \\
\hline \multirow{2}{*}{ School level } & \multicolumn{2}{|c|}{ Bachelor's degree } & 28 & 59.6 \\
\hline & \multicolumn{2}{|c|}{ Postgraduate } & 1 & 2.1 \\
\hline \multirow{3}{*}{ Age } & \multicolumn{2}{|c|}{ Other } & 7 & 14.9 \\
\hline & Min & $\operatorname{Max}$ & Mean & $\mathrm{SD}$ \\
\hline & 23 & 57 & 40.51 & 9.773 \\
\hline Work seniority & 1 & 33 & 17.62 & 9.958 \\
\hline
\end{tabular}

Note: $\mathrm{n}=$ frequency; SD, standard deviation; Min, Minimum; Max, Maximum; sample = 47 . 


\subsection{Psychosocial Factors at Work}

In Table 2 we can observe results obtained from the survey "Factores Psicosociales en el Trabajo" (Psychosocial factors at work) adapted version. The data showed high values in the means for global score (83.55), meanwhile, when analyzing by dimension, the highest values were in the Work demands (22.94), followed by Workplace conditions (13.47) and Social interactions and organizational aspects (13.40).

\subsection{Quality of Work Life}

Regarding QWL, the results indicated a global score of 191.83. Table 3 presents the data divided by dimensions, observing that the highest values were in the dimension Wellbeing accomplished through work (36.43), followed by Institutional support for work (34.11) and Work satisfaction (31.32). The lower scores were in the dimension Free time administration (10.79).

Table 2. Mean scores for the survey "Factores Psicosociales en el Trabajo" (Psychosocial factors at work).

\begin{tabular}{lcccc}
\hline \multicolumn{1}{c}{ Dimension } & Min & Max & Mean & SD \\
\hline Workplace conditions & 1 & 27 & 13.47 & 4.898 \\
Workload & 1 & 15 & 7.40 & 3.208 \\
Content and characteristics of the task & 0 & 15 & 9.74 & 3.061 \\
Work demands & 16 & 28 & 22.94 & 3.280 \\
Professional role and career development & 0 & 15 & 9.15 & 3.336 \\
Social interaction and organizational aspects & 5 & 24 & 13.40 & 4.928 \\
Performance remuneration & 1 & 12 & 7.45 & 3.133 \\
Global score & 39 & 121 & 83.55 & 17.413 \\
\hline
\end{tabular}

Note: Min, Minimum; Max, Maximum; SD, Standard Deviation; Source: survey "Factores Psicosociales en el Trabajo" (Psychosocial factors at work) adapted version; sample $=47$.

Table 3. Mean scores for the survey Calidad de vida en el trabajo (Quality of work life) CVT-GOHISALO.

\begin{tabular}{lcccc}
\hline \multicolumn{1}{c}{ Dimension } & Min & Max & Mean & SD \\
\hline Institutional support for work & 17 & 56 & 34.11 & 8.636 \\
Work safety & 15 & 60 & 29.57 & 8.480 \\
Integration to the work position & 16 & 40 & 28.79 & 5.505 \\
Work satisfaction & 17 & 44 & 31.32 & 6.137 \\
Wellbeing accomplished through work & 25 & 44 & 36.43 & 4.063 \\
Personal development & 8 & 32 & 20.83 & 4.687 \\
Free time administration & 1 & 20 & 10.79 & 2.934 \\
Global score & 118 & 296 & 191.83 & 31.540 \\
\hline
\end{tabular}

Note: Min, Minimum; Max, Maximum; SD, Standard Deviation; Source: survey Calidad de vida en el trabajo (Quality of work life) CVT-GOHISALO; sample $=47$. 


\subsection{Association between Psychosocial Factors at Work and Quality of Work Life}

The association between the study variables was calculated using chi-square. The results are presented in Table 4, indicating that the psychosocial dimension Content and characteristics of the task was associated with six scales of the quality of work life measurement, excepting the dimension Work satisfaction. Likewise, the factor Workload presented significant associations with four QWL dimensions. The stronger associations were between the Performance remuneration and Work safety $(p<0.001)$, and for Content and characteristic of the task with Institutional support for work $(p<0.001)$.

The variables that presented significant association values were submitted to a correlation analysis using Spearman Coefficient. The results obtained are in Table 5, in which the QWL dimension Work satisfaction was eliminated because it did not presented any significant association in the previous analysis.

The psychosocial dimension content and characteristic of the task remained with the higher number of correlations, observing significant values in several QWL dimensions. The stronger correlations were between the dimensions Performance remuneration and Work safety $(p<0.01)$, as well as the scales Professional role and career development and personal development $(p<0.01)$. Also, the correlation between the global scores of both surveys was calculated, observing a significant correlation $(p<0.01)$. It is noteworthy that all the correlations maintained a positive direction.

\section{Discussion}

The aim of this study was to determine the association between the psychosocial risk factors and quality of work life in air traffic controllers in an Ecuador

Table 4. Association between psychosocial work factors and quality of work life.

\begin{tabular}{|c|c|c|c|c|c|c|c|}
\hline \multirow[b]{2}{*}{$\begin{array}{c}\text { Psychosocial Work } \\
\text { Factors }\end{array}$} & \multicolumn{7}{|c|}{ Quality of Work Life } \\
\hline & $\begin{array}{c}\text { Institutional } \\
\text { support for work }\end{array}$ & Work safety & $\begin{array}{l}\text { Integration to the } \\
\text { work position }\end{array}$ & $\begin{array}{c}\text { Work } \\
\text { satisfaction }\end{array}$ & $\begin{array}{c}\text { Wellbeing } \\
\text { accomplished } \\
\text { through work }\end{array}$ & $\begin{array}{c}\text { Personal } \\
\text { development }\end{array}$ & $\begin{array}{c}\text { Free time } \\
\text { administration }\end{array}$ \\
\hline Workplace conditions & $0.05^{*}$ & 0.44 & 0.15 & 0.15 & 0.43 & 0.33 & 0.44 \\
\hline Workload & $0.02^{*}$ & 0.45 & $0.01^{* *}$ & 0.11 & $0.03^{*}$ & 0.48 & $0.05^{*}$ \\
\hline $\begin{array}{c}\text { Content and characteris- } \\
\text { tics of the task }\end{array}$ & $0.00^{* *}$ & $0.02^{*}$ & $0.01^{* *}$ & 0.07 & $0.02^{*}$ & $0.02^{*}$ & $0.04^{*}$ \\
\hline Work demands & $0.03^{*}$ & 0.43 & 0.40 & 0.41 & 0.17 & 0.17 & 0.31 \\
\hline $\begin{array}{l}\text { Professional role and } \\
\text { career development }\end{array}$ & $0.05^{*}$ & 0.15 & 0.28 & 0.46 & 0.14 & $0.01^{* *}$ & 0.15 \\
\hline $\begin{array}{l}\text { Performance } \\
\text { remuneration }\end{array}$ & 0.23 & $0.00^{* *}$ & 0.15 & 0.22 & 0.33 & 0.09 & 0.32 \\
\hline
\end{tabular}

Note: We considered significant the associations with a $p<0.05 ;{ }^{\star} p<0.05 ;{ }^{\star *} p<0.01$. 
Table 5. Correlations coefficients for the associations between psychosocial work factors and quality of work life.

\begin{tabular}{|c|c|c|c|c|c|c|c|c|c|c|c|c|}
\hline \multirow{3}{*}{$\begin{array}{c}\text { Psychosocial Work } \\
\text { Factors }\end{array}$} & \multicolumn{12}{|c|}{ Quality of Work Life } \\
\hline & \multicolumn{2}{|c|}{$\begin{array}{c}\text { Institutional } \\
\text { support for work }\end{array}$} & \multicolumn{2}{|c|}{ Work safety } & \multicolumn{2}{|c|}{$\begin{array}{l}\text { Integration to the } \\
\text { work position }\end{array}$} & \multicolumn{2}{|c|}{$\begin{array}{l}\text { Wellbeing } \\
\text { accomplished } \\
\text { through work }\end{array}$} & \multicolumn{2}{|c|}{$\begin{array}{c}\text { Personal } \\
\text { development }\end{array}$} & \multicolumn{2}{|c|}{$\begin{array}{c}\text { Free time } \\
\text { administration }\end{array}$} \\
\hline & $r^{2}$ & $P$ & $r^{2}$ & $P$ & $\mathrm{r}^{2}$ & $P$ & $\mathrm{r}^{2}$ & $P$ & $\mathrm{r}^{2}$ & $P$ & $r^{2}$ & $P$ \\
\hline Workplace conditions & 0.2262 & $0.03^{*}$ & & & & & & & & & & \\
\hline Workload & 0.1102 & 0.06 & & & 0.1814 & $0.00^{* *}$ & 0.1714 & $0.01^{* *}$ & & & 0.0442 & $0.04^{*}$ \\
\hline $\begin{array}{l}\text { Content and characte- } \\
\text { ristics of the task }\end{array}$ & 0.2067 & $0.02^{*}$ & 0.1847 & $0.03^{*}$ & 0.1357 & $0.01^{\star *}$ & 0.1079 & $0.03^{*}$ & 0.0336 & 0.14 & & \\
\hline Work demands & 0.0279 & 0.25 & & & & & & & & & & \\
\hline $\begin{array}{l}\text { Professional role and } \\
\text { career development }\end{array}$ & 0.158 & $0.04^{*}$ & & & & & & & 0.2558 & $0.00^{* *}$ & & \\
\hline $\begin{array}{l}\text { Social interaction and } \\
\text { organizational aspects }\end{array}$ & 0.3676 & $0.00^{* *}$ & & & 0.0939 & 0.06 & & & & & & \\
\hline $\begin{array}{l}\text { Performance } \\
\text { remuneration }\end{array}$ & & & 0.1667 & $0.00^{* *}$ & & & & & & & & \\
\hline
\end{tabular}

Note: We considered significant the associations with a $p<0.05 ;{ }^{*} p<0.05 ;{ }^{* *} p<0.01$.

airport. The main results indicated that the psychosocial factor Content and characteristics of the task presented a higher presence of associations with the quality of work life perception, followed by the Workload dimension.

Beginning to talk about the psychosocial factors at work, we found that the dimension work demands scored the higher mean, finding consisting with the reported by several researches that point out that ATC's have constant psychological demands, such as the requirement of quick decision making and the maintaining of high levels of mental alertness (Sayeed \& Kumar, 2010; van de Merwe, Oprins, Eriksson, \& van der Plaat, 2012). At a second place, we found the dimension Workplace conditions, referring to the perception of a high presence of work conditions that could represent a psychosocial risk factor, one of which could be the rotating shifts (Sonati, De Martino, Vilarta, da Silva Maciel, Sonati, \& Paduan, 2016). Also, with close mean values, the dimension Social interactions and organizational aspects, scored in the third place, and this result indicates the presence of factors related with negative social interactions and organizational characteristics at work, maybe be because of the individualistic and demanding job description (Vargas, Guimarães, \& Sant'Anna, 2012). This result indicates that the participants perceive the presence of important psychosocial demands and a low level of control over them, because of the organizational characteristics of their work. According to Karasek \& Theorell (1990), this unbalance between the level of demands and the perceived control over them, could favor a stress response, which, when present over time, could become a risk for the development of future health problems at different levels.

Regarding the quality of work life, the results indicated that the dimension with higher means was the Wellbeing accomplished through work, followed by 
Institutional support for work and Work satisfaction. This discovery suggests that, although the participants referred to have a high presence of psychosocial risk factors such as work demands and negative workplace conditions, they might find a sense of wellbeing or meaning through the work developed. This result indicates that they might be finding some level of satisfaction and transcendence thought their work, maybe because of the low level of ATC's in the country or the high qualifications they need to have to develop this job. Considering this finding, the future research develop with this populations needs to include the variable QWL, because it is a factor shallowly taken into consideration in the existing studies that include ATC's, despite its influence in the work satisfaction and performance, an important aspect of this professional activity, considering the degree of responsibility that involves.

The results obtained for the analysis of the association of the study variables showed that, the psychosocial factor Content and characteristics of the task presented the higher number of associations with the QWL dimensions. The Workload factor also presented association with the integration and wellbeing QWL dimensions, adding the Free time administration. Both variables presented positive directions in the associations found with the QWL variables. This finding is relevant and closely related, because, as pointed by several authors, the ATC's perform a series of simultaneous activities and tasks that require a high level of concentration and mental alertness, characteristics that generate an important cognitive workload that could affect different areas of the human development (Sayeed \& Kumar, 2010; van de Merwe, Oprins, Eriksson, \& van der Plaat, 2012). According to this result, the presence of demanding work activities that represent an important workload affect the perception of the work support, integration and wellbeing accomplished through work, also influencing the management of free time, maybe because of variables such as shift rotation. The areas of the QWL associated with the presence of psychosocial factors at work are important aspects of the professional and personal development, being necessary to explore this association including other variables and under different statistical analysis. Aiming to identify the work variables that impact in the personal and professional development of this population, in order to develop future prevention strategies that prevent mental and physical problems.

One of the limitations of this study is that we collected data for the air traffic controllers of only one airport in Ecuador, being a small sample. It is necessary to increase the sample with ATC's from other parts of the country or from different countries, in order to compare the results obtained. Also, it would be important to explore the differences existing by sociodemographic variables in the perception of the presence of psychosocial work factors and quality of work life, identifying if there are any groups in more risk for the development of health problems.

However, despite these limitations, the study represents an important contribution to existing knowledge about the ATC's work, providing information about elements shortly approached in research, such as their perception of the 
psychosocial factors present in the work conditions, the quality of work live and the association between those variables.

\section{Acknowledgements}

To the University of Guadalajara and the Consejo Nacional de Ciencia y Tecnologia (National Science and Technology Council CONACyT), Mexico.

\section{References}

Arenas, F., \& Andrade, V. (2013). Psychosocial Risk Factors and Work (Engagement) in a Health Care Institution in the City of, Cali-Colombia. Acta Colombiana de Psicología, 16, 43-56.

Crump, J. H. (1979). Review of Stress in Air Traffic Control: Its Measurement and Effects. Aviation Space and Environmental Medicine, 50, 243-248.

Central Intelligence Agency (2013). The World Factbook 2013-14. Washington DC: Central Intelligence Agency.

González, R., Hidalgo, G., Salazar, J., \& Preciado, M. (2009). Development and Validation of an Instrument for Measuring Quality of Life at the Workplace "CVT-GOHISALO". Guadalajara: Ediciones de la Noche.

González, B., Hidalgo, S., Salazar, E., \& Preciado, S. (2010). Elaboracióny Validación del Instrumento para Medir Calidad de Vida en el Trabajo "CVT-GOHISALO". Ciencia \& Trabajo, 12, 332-340.

Kamali, M., \& Chirayath, S. (2017). Impact of Demographic Variables on Quality of Work Life: An Analysis on Policepersonnel's of Tamil Nadu Police Department in Tirunelveli City. International Journal of Research in Commerce \& Management, 8, 1823.

Karasek, R., \& Theorell, T. (1990). Healthy Work: Stress, Productivity, and the Reconstruction of Working Life. New York: Basic Books.

Lopez, M. (2012). Relevance of the Psychosocial Risks in Air Traffic Controllers. http://www.unir.net/ciencias-sociales/revista/noticias/importancia-del-riesgo-psicosoci al-en-controladores-aereos/549201447342/

Maldonado, P. (19 de Octubre de 2015). Ecuador Has 220 Air Traffic Controllers. El comercio.

http://www.elcomercio.com/actualidad/ecuador-controladores-aereos-aeropuertos.html

Mansilla, F. (2012). Manual of Psychosocial Risk at Work. Madrid: Editorial Académica Española.

Pando, M., Varillas, W., Aranda, C., \& Elizalde, F. (2016). Exploratory and Factorial Analysis of the 'Questionnaire of Psychosocial Factors at Work' in Peru. Anales de la Facultad de Medicina, 77, 365-371.

Poza de la, J., \& Prior, J. (1988). Quality of Work Life. An Empiric Analysis. At Official College of Psychology of Madrid. Book of the First Iberoamerican Congress and the Third National of Wok and Organizations Psychology (pp. 470-476). Madrid: Colegio Oficial de Psicólogos.

Sánchez, R., \& Lina, M. (2008). Aerospace Medicine and Human Factors in Aviation. The Importance of a Transdisciplinary Approach to Health. Revista Medica, 16, 249-260.

Sayeed, O., \& Kumar, S. (2010). Role, Work Perception \& Stress in a High Reliability Work Environment. The Indian Journal of Industrial Relations, 46, 287-299. 
Siegrist, J. (2007). Psychosocial Factors and Stress. In G. Fink (Ed.), Stress Consequences Mental, Neuropsychological and Socioeconomic. San Diego, CA: Academic Press. https://doi.org/10.1016/B978-012373947-6.00319-6

Silva, N. (2006). Psychosocial Factors and Professional Wear down in Academics of the University Center of Biologic and Agropecuary Sciences. Ph.D. Thesis, Guadalajara: Universidad de Guadalajara.

Sonati, J. G., De Martino, M. F., Vilarta, R., da Silva Maciel, É., Sonati, R. F., \& Paduan, P. C. (2016). Quality of Life, Sleep, and Health of Air Traffic Controllers with Rapid Counterclockwise Shift Rotation. Workplace Health \& Safety, 64, 377-384.

https://doi.org/10.1177/2165079916634710

Van de Merwe, K., Oprins, E., Eriksson, F., \& van der Plaat, A. (2012). The Influence of Automation Support on Performance, Workload, and Situation Awareness of Air Traffic Controllers. The International Journal of Aviation Psychology, 22, 120-143 https://doi.org/10.1080/10508414.2012.663241

Vargas, C., Guimarães, L., \& Sant'Anna, A. (2012). Analysis of the Work of Air Traffic Controllers of the Approach Control Area (APP) of Porto Alegre, Brazil. Work, 41, 151-158.

\section{Submit or recommend next manuscript to SCIRP and we will provide best service for you:}

Accepting pre-submission inquiries through Email, Facebook, LinkedIn, Twitter, etc. A wide selection of journals (inclusive of 9 subjects, more than 200 journals) Providing 24-hour high-quality service User-friendly online submission system Fair and swift peer-review system Efficient typesetting and proofreading procedure Display of the result of downloads and visits, as well as the number of cited articles Maximum dissemination of your research work

Submit your manuscript at: http://papersubmission.scirp.org/ Or contact psych@scirp.org 